EPRA International Journal of Economic and Business Review-Peer Reviewed Journal

Volume - 9, Issue - 6, June 2021 | e-ISSN: 2347 - 9671| p- ISSN: 2349 - 0187

\title{
IN-DEPTH ASSESSMENT OF THE IMPACT OF COVID-19 ON INDIAN ECONOMY
}

\author{
${ }^{1}$ Dr. Mahesh Kumar Kurmi, ${ }^{2}$ Dr. Baneswar Kapasi \\ ${ }^{1}$ Assistant Professor, Department of Commerce, Kazi Nazrul University, Asansol Paschim Bardhaman, \\ West Bengal, Pin - 713340 \\ ${ }^{2}$ Associate Professor, Department of Commerce, Kazi Nazrul University, Asansol Paschim Bardhaman, \\ West Bengal, Pin - 713340
}

*Corresponding Author: Dr. Mahesh Kumar Kurmi

\section{ABSTRACT}

DOI No: $10.36713 /$ epra7453

Article DOI URL: https://doi.org/10.36713/epra7453

Mending the deteriorating state of the world economy caused by the outbreak of COVID-19 is the biggest challenge in the new millennium. The shocking effects of the pandemic have not only affected the socio-cultural lives of the people but have also stunned the economies across the world. The world economy is passing through great uncertainty in this pandemic situation. Economists predict that the economic impact of the pandemic could be worse than the world economic crisis of 1930. Indian economy is also not beyond the sphere of COVID -19. This pandemic has impacted all sectors of the Indian economy, whether it is primary or secondary or tertiary or even Quaternary. No part of the vital segments of the Indian economy such as trade, production, demand, tourism and business travel, investment, and investor sentiment has been spared from its harsh effects. Undoubtedly, COVID-19 has severely affected the Indian economy, but how profound was the impact of COVID-19 on the Indian economy? That is the question of this research paper. Thus, considering various indicators of economy such as GDP, unemployment rate, net exports, and GST collections, an attempt has been made here to compare the state of the Economy in FY 2020-21 with that of FY 2019-20 so that at least the immediate impact of COVID-19 on the Indian economy can be assessed.

KEYWORDS: COVID-19, Indian Economy, GDP, Unemployment Rate, Net Export, GST

\section{INTRODUCTION}

Controlling the ill effects of COVID-19 on social, economic, political, and cultural life is a tough challenge for all countries, irrespective of the nature of the economy. Although the virus was first diagnosed in China but has been spread to more than 200 countries in a short time. The virus entered India in January 2020. To control the unprecedented situation, the Government of India has accepted the World Health Organisation (WHO) guidelines like social distancing, restriction of travel at the national and international level, and closure of educational institutions. In addition, the citizens are asked to stay in homes during the lockdown period.

Limiting the movement of population to control the spread of the virus and as a preventive measure for COVID, on March 19, 2020, the Prime Minister of India announced and asked all citizens to observe the 
"Janata Curfew on March 2020. On March 24, the Government of India (GOI) ordered a lockdown for 21 days. GOI again on April 14 extended the lockdown until May 3. In May, the Government extended the lockdown further for two weeks (Until May 17). The National Disaster Management Authority (NDMA) extended the lockdown till May 31, 2020. GOI extended the lockdown restriction till June 30 for the containment zones. Unlock process was started in a phase-wise manner starting from June 8, 2020, in the term of "Unlock-1.0". The second phase of Unlock-2.0 was announced from July 1 to July 31, 2020, with more relaxation. Unlock 3.0 was announced for August 2020, Unlock 4.0 was announced for September 2020, Unlock 5.0 was announced for October 2020, Unlock 6.0 was announced for November 2020, and Unlock 7.0 was announced for December 2020.

Coronavirus outbreaks and prolonged lockdown have impacted every part of our lives. COVID-19 pandemic has taken the whole world under threat by surprise. The most critical impact of the COVID-19 pandemic has been witnessed on the Indian economy, especially regarding employment and income generation. The majority of the Indian population depends upon daily income. This COVID-19 and subsequent prolonged lockdown made many populations of India unemployed because a large part of the employment in India works in the unorganized sector; the lack of work due to the lockdown forced the migrant laborers to return to their hometown.

As per the statistics of Center for Monitoring Indian Economy (CMIE), a total of 12 crore works have been lost due to the lockdown. Before the Corona crisis, the total employment population in India was 40.4 crores, which has come down to 28.5 crores after this crisis. Consumer spending has also been the worst hit due to the loss of jobs. The Indian economy, which was already going through a slowdown before the pandemic, is now facing sluggish consumer demand as household incomes have declined due to the pandemic's loss. The GST collection in April 2020 has been relatively poor as the collection of GST witnessed a sudden drop of $71.63 \%$. In addition, international trade has also been impacted due to quiescent transport and distribution system. A sudden drop of $39.63 \%$ in exports and 50.94\% in imports was observed in April 2020 compared to 2019.

Undoubtedly, COVID-19 has severely affected the Indian economy, but how profound was the impact of COVID-19 on the Indian economy? That is the question of this research paper. Thus, considering various aspects such as GDP, unemployment rate, net exports, and GST collections, a humble attempt has been made to compare the state of the Economy in FY 2020-21 with that of FY 2019-20 so that at least the immediate impact of COVID-19 on the Indian economy can be assessed.

The arrangement of the paper is as follows: section two summarizes the literature review of previous studies in this area, section three provides a look at the aims of the study, section four highlights the hypothesis, section five provides the methodology to be followed in this research, section six focuses on the analysis of data and discussion of the results and findings, and finally, section seven deals with the conclusions of the research.

\section{SURVEY OF EXISTING LITERATURE}

India is a highly populated developing economy that more or less depends on primary, secondary, and tertiary sectors. Some of the Indian population is under the BPL limit and is dependent on daily income. Per capita health expenditure, health awareness, and health infrastructure are not up to the mark. Communication technology and the Internet are facing the problem of density accuracy. Many producers, suppliers, and customers rely purely on physical distribution channels. Under this economic condition, the Corona outbreak is an economic disaster for India. All aspects of the Indian economy have been badly affected due to the health emergency COVID outbreak and various types of lockdowns since March 2020.

Though a limited number of studies have been conducted so far to assess the impact of COVID-19 on the Indian economy, various news reports in the electronic and print media have carried out some studies on the issue. In addition, various economic and financial agencies have also conducted some studies to assess the impact of COVID-19 on the Indian economy concerning various economic indicators and economic sectors.

B. Kapasi and M.K. Kurmi (2021), through their paper titled "A Knock around the Economic Impact of COVID-19 with reference to the quantum of Goods and Services Tax Collection in India" attempted to assess the impact of COVID-19 on the Indian economy concerning the quantum of Goods and Service collection in Indian during the lockdown period. Their study was based on secondary data which was collected from the official websites of the GST Council of India for the last three years, i.e., 2018 to 2020. They applied a paired ttest for testing the statistical significance of the impact of COVID-19 on the quantum of the collection of Goods and Service Tax in India before and after lockdown announcement after adjusting the inflation factor. Findings of the study revealed that no significant difference in the quantum of Goods and Services Tax Collection in India is observed before and after the lockdown announcement due to the COVID-19 outbreak but a loss of ₹ 1,41,837 crore owing to the low collection of GST from March 2020 to August 2020 gives a clear message that it is time to reconsider the plans in more operational and more feasible ways to reach a situation to captivate any kinds of undefined pressures from the external environment. 
Haiyu Liu et al. (2020) have conducted a study on the COVID-19 outbreak and the stock market response of the affected countries. They have assessed the short-term impact of COVID-19 on twenty-one major stock markets through an event study methodology. They conclude that the impact of COVID-19 on Asian countries is unusually negative compared to other countries in the COVID situation.

J.D. Sonkhaskar (2020), through his article 'Impact of COVID-19 on Indian Economy', attempted to give an overview of the status of COVID-19 in India, the state of the Indian economy before the pandemic, its impact on various sectors. He has also tried to highlight the policy recommendations and strategies prepared by the Government of India to mitigate the financial disaster. He has detailed the region-wise impact of the pandemic situation and suggested various strategies to mitigate the economic losses in the Indian scenario.

K. D. Garg, M. Gupta, and M. Kumar (2020) have tried to evaluate the impact of COVID-19 on India's Economy through their article "Impact of the COVID-19 Pandemic on the Indian Economy by Machine Learning". They have tried to analyze the impact of COVID-19 on the Indian Stock Market vs. COVID-19 patients in India from March 2020 to July 2020. They have used machine learning to predict the opening SENSEX rate by using different regression models. This research concludes that the increasing number of COVID-19 cases directly impacted the stock market.

M. Chowdhary, P.R. Sodani, and S. Das (2020), through his article "Impact of COVID-19 on the Economy in India: Reflections for Policy and Programme," has assessed the impact of the Corona outbreak on the affected sectors. They have highlighted the impact of COVID-19 on aviation, tourism, tourism, retail, capital markets, MSMEs and oil sectors. They have suggested that India's policymakers should rethink the growth paradigm more inclusively with the help of some reforms in the labor market sector.

N Arora and V Gupta (2020) have made an effort to analyse sector-wise impact of Covid-19 on Indian Economy through their article "A Study on Impact of COVID-19 on Indian Economy". They have used a descriptive research design in this study. They have used the secondary economic data from March 2020 to June 2020. They have assessed the sectoral impact of COVID on India's Economy.

S. Agarwal and A. Singh (2020), in their study 'COVID-19 and its impact on the Indian economy, have put an effort to depict the ripples of COVID-19 on various sectors of the Indian Economy. Authors have focused on those economic sectors that grasp a boost due to the outbreak of COVID-19. They considered secondary data to assess the economic conditions from December 2019 to May 2020. Interestingly, he made twenty-four suggestions to mitigate the impact of the pandemic on the Indian economy after considering the effects of the pandemic on the demand front, supply front, financial market, international trade, and economic growth.

There is no good number of studies done so far on the impact of COVID-19 on the Indian economy, and the studies that have been done are, in fact, a very preliminary assessment of the impact of COVID-19. Therefore, through this research article, we have made a sincere effort to make a short-term assessment of the impact of COVID-19 on the Indian economy by comparing the situation in FY 2020-21 with that of FY 2019-20, considering various aspects like GDP, unemployment rate, net exports, and GST collection.

\section{OBJECTIVES OF THE STUDY}

The general objective of the study is to assess the impact of COVID-19 on the Indian economy, but the specific objectives of this study are-

(a) to evaluate the consequence of COVID-19 on the GDP growth rate of India

(b) to assess the impact of COVID-19 on the unemployment rate in India

(c) to measure the influence of COVID-19 on net Export of India

(d) to weigh the bearing of COVID-19 on GST Collection in India

\section{HYPOTHESIS OF THE STUDY}

Following are the hypothesis of the study-

Hypothesis 1: There is no significant difference in the GDP growth rate before and during the COVID-19 in India.

Rejection of the null hypothesis indicates a statistically significant difference in the GDP growth rate before and during the COVID-19 in India.

Hypothesis 2: There is no significant difference in the unemployment rate before and during the COVID-19 in India.

Rejection of the null hypothesis indicates a statistically significant difference in the unemployment rate before and during the COVID-19 in India.

Hypothesis 3: There is no significant difference in net Export before and during the COVID-19 in India.

Rejection of the null hypothesis indicates a statistically significant difference in net Export before and during the COVID-19 in India. 
Hypothesis 4: There is no significant difference in Goods and Services Tax collection in India before and during the COVID-19 in India.

Rejection of the null hypothesis indicates a statistically significant difference in Goods and Services Tax collection in India before and during the COVID-19 in India.

\section{RESEARCH METHODOLOGY}

Descriptive and exploratory research methods have been used in this study. In fact, it is a post-facto analysis. This study has been constructed with the help of secondary data, and all required facts are extracted from the various relevant official site of the Government of India. Data has been collected and analyzed regarding various important economic indicators like GDP growth rate, unemployment rate, net exports, and GST collection in India during FY 2019-20 and FY 2020-21. The data regarding quarterly GDP for the above period has been collected from the data released by the National Statistical Office (NSO), Ministry of Statistics, and Program Implementation (MoSPI). India's Total Monthly Exports and India's Total Monthly Import data during the said period has been pooled from the official website of the Ministry of Commerce \& Industry, the Government of India, and the official site of the Reserve Bank of India. Data concerning the unemployment rate have been collected from the facts and figures released by the Centre for Monitoring Indian Economy Pvt. Ltd.(CMIE). Data relating to GST collection have been assembled from the official websites of the GST Council of India. Taking into account the various indicators of the Economy like GDP growth rate, unemployment rate, net exports, and GST collections, an attempt has been made to compare the state of the Economy in FY 2020-21 with that of FY 2019-20 so that at least The immediate impact of COVID-19 on the Indian economy can be assessed. Finally, to arrive at a specific conclusion on whether the immediate impact of COVID-19 on the Indian economy was statistically significant, the paired t-test is applied here.

\section{FINDINGS AND DISCUSSIONS}

6.1 IMPACT OF COVID ON GDP OF INDIAN ECONOMY: Gross Domestic Product of a country represents the monetary measurement of the total market value of all the goods and services produced in the economy for a particular year. As per The National Statistical Office (NSO), Ministry of Statistics and Programme Implementation, GDP is resultant as the aggregate of the gross value added (GVA) at basic prices plus entire taxes (includes non-GST and GST revenue ) on products less total subsidies provided on products. GDP growth rate on a YoY basis represents the change of the GDP concerning the GDP of the previous year. The formula uses to calculate GDP growth rate is $=\left(\mathrm{GDP}_{\mathrm{t}}-\mathrm{GDP}_{\mathrm{t}-1}\right) / \mathrm{GDP}_{\mathrm{t}-1}$ where $\mathrm{GDP}_{\mathrm{t}}$ represents the Gross State Domestic Product in a particular(t) year, and $\mathrm{GDP}_{\mathrm{t}-1}$ represents the GDP of the previous year.

Table 1 indicates that the GDP at constant (2011-12) prices in the first quarter of 2020-21 is ₹26.95 lakh crore, as against ₹35.67 lakh crore in the first quarter of 2019-20, demonstrating a shrinkage of 24.4 percent as compared to 5.4 percent growth in the first quarter of 2019-20. This contraction of GDP in the first quarter of 2020-21 is the worst in the history of the Indian economy, which occurred owing to the strict nationwide lockdown during the coronavirus (COVID-19) pandemic. However, the phase-wise unlock process has relieved the Indian economy in the second quarter after fronting a negative growth of 24.4 percent in the first quarter of 2020-21 because GDP at constant (2011-12) prices in the second quarter of 2020-21 stood at ₹ 32.97 lakh crore as against ₹ 35.62 lakh crore in the second quarter of 2019-20, showing a contraction of 7.4 percent as compared to 4.6 percent growth in Q2 2019-20. 
Table 1: Quarterly estimates of GDP and GVA at Basic prices in Q1, Q2, Q3, and Q4 of 2019-20 and 2020-21 (at 2011-12 prices)

\begin{tabular}{|c|c|c|c|c|c|c|c|c|c|c|c|c|c|c|c|c|}
\hline \multirow{4}{*}{ Industry } & \multicolumn{16}{|c|}{ GVA at basic prices } \\
\hline & \multirow{2}{*}{\multicolumn{4}{|c|}{ 2019-20 (Rs. in crore) }} & \multirow{2}{*}{\multicolumn{4}{|c|}{ 2020-21 (Rs. in crore) }} & \multicolumn{8}{|c|}{ Percentage Change Over Previous Year } \\
\hline & & & & & & & & & \multicolumn{4}{|c|}{ 2019-20 } & \multicolumn{4}{|c|}{ 2020-21 } \\
\hline & Q1 & Q2 & Q3 & Q4 & Q1 & Q2 & Q3 & Q4 & Q1 & Q2 & Q3 & Q4 & Q1 & Q2 & Q3 & Q4 \\
\hline 1. Agriculture, forestry \& fishing & 449390 & 378602 & 612460 & 528119 & 465280 & 390106 & 640191 & 544503 & 3.3 & 3.5 & 3.4 & 6.8 & 3.5 & 3.0 & 4.5 & 3.1 \\
\hline 2. Mining \& quarrying & 82914 & 64905 & 77427 & 96870 & 68680 & 60671 & 73990 & 91303 & -1.3 & -5.2 & -3.5 & -0.9 & -17.2 & -6.5 & -4.4 & -5.7 \\
\hline 3. Manufacturing & 567516 & 564742 & 546580 & 590586 & 363448 & 556233 & 555884 & 631503 & 0.6 & -3.0 & -2.9 & -4.2 & -36.0 & -1.5 & 1.7 & 6.9 \\
\hline $\begin{array}{l}\text { 4. Electricity, gas, water supply\& } \\
\text { other utility services }\end{array}$ & 79654 & 77469 & 70512 & 72898 & 71800 & 79242 & 75651 & 79561 & 6.9 & 1.7 & $\mid-3.1$ & 2.6 & $\mid-9.9$ & 2.3 & 7.3 & 9.1 \\
\hline 5. Construction & 260099 & 241188 & 257010 & 277236 & 131439 & 223773 & 273670 & 317514 & 3.7 & 1.0 & $\mid-1.33$ & 0.7 & -49.5 & -7.2 & 6.5 & 14.5 \\
\hline $\begin{array}{l}\text { 6. Trade, hotels, transport, } \\
\text { communication and services } \\
\text { related to broadcasting }\end{array}$ & 664311 & 638065 & 663688 & 733734 & 345099 & 535234 & 611248 & 716808 & 6.2 & 6.8 & 7.0 & 5.7 & -48.1 & -16.1 & -7.9 & -2.3 \\
\hline $\begin{array}{l}\text { 7. Financial, real estate \& } \\
\text { professional services }\end{array}$ & 802241 & 862867 & 620490 & 630911 & 761791 & 784329 & 661868 & 664827 & 8.8 & 8.9 & 5.5 & 4.9 & -5.0 & -9.1 & 6.7 & 5.4 \\
\hline $\begin{array}{l}\text { 8. Public administration, defence } \\
\text { and Other Services }\end{array}$ & 399148 & 443615 & 456723 & 459502 & 358373 & 402697 & 446771 & 469945 & 5.6 & 8.8 & 8.9 & 9.6 & -10.2 & -9.2 & -2.2 & 2.3 \\
\hline 9. GVA at Basic Price & 3305273 & 3271453 & 3304890 & 3389855 & 2565909 & 3032285 & 3339272 & 3515963 & 5.0 & 4.6 & 3.4 & 3.7 & -22.4 & -7.3 & 1.0 & 3.7 \\
\hline 10. GDP & 3566708 & 3561530 & 3607630 & 3833401 & 2695421 & 3296718 & 3624266 & 3896335 & 5.4 & 4.6 & 3.3 & 3.0 & -24.4 & -7.4 & 0.5 & 1.6 \\
\hline
\end{tabular}

Source: National Statistical Office (NSO), Ministry of Statistics \& Programme Implementation (MoSPI)

The economy snapped out of a technical slowdown in the third quarter of the financial year 2020-21 and grew at a revised 0.5 percent rate after reporting a strike in growth for two consecutive quarters of the same financial year. As a result, in the third quarter of 2020-21, the GDP at Constant (2011-12) Prices is reported at ₹ 36.24 lakh crore, as against ₹ 36.08 lakh crore in the third quarter of 2019-20, which specifies a nominal growth of 0.5 percent as compared to 3.3 percent growth in the third quarter of 2019-20. GDP at Constant (2011-12) Prices 2020-21 stood at ₹ 38.96 lakh crore in the fourth quarter of 2020-21 as against ₹ 38.33 lakh crore in the same quarter of 2019-20. Consequently, amid the coronavirus pandemic, India's Gross Domestic Product (GDP) saw a growth of 1.6 percent in the fourth quarter of the financial year 2020-21 as compared to 3 percent growth in the fourth Quarter of 2019-20 because the Indian economy was trying to get back on track.

Figure 1 demonstrates the Quarterly GDP Growth Rate in Q1, Q2, Q3, and Q4 of 2019-20 and 2020-21 (at 2011-12 prices).

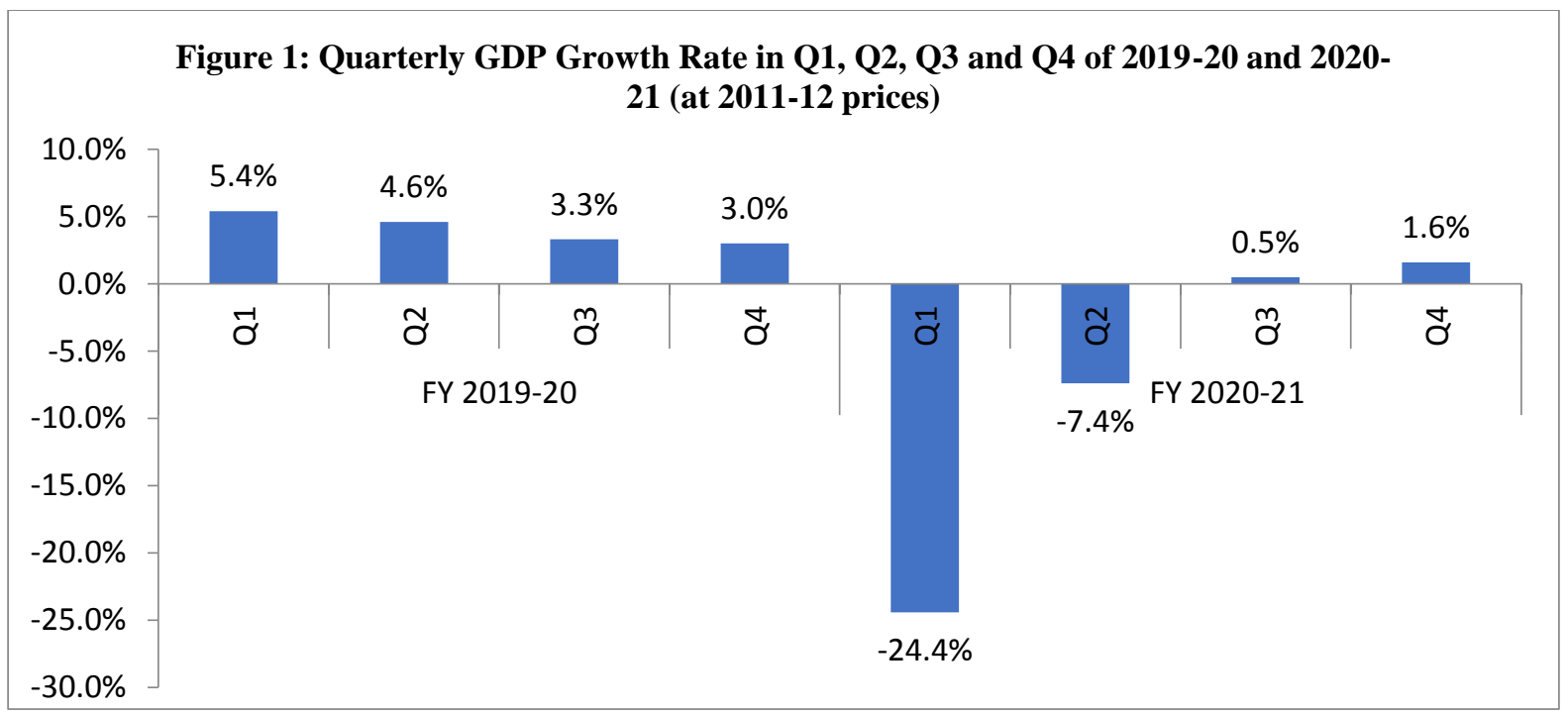

India's GDP figures for the financial year 2020-21 registered a decline of 7.3 percent, while the growth rate for the financial year 2019-20 fell to an 11 -year low of 4 percent. This is the first full-year shrinkage in the Indian economy in the past four decades since 1979-80, when GDP contracted by 5.2 percent. 


\subsection{IMPACT OF COVID ON UNEMPLOYMENT RATE IN INDIA}

The unemployment rate is the percentage of the unemployed population due to the non-availability of employment in an economy. It refers to the economy's inability to generate employment for individuals who want to work but are not doing so, even if they are available for employment and actively looking for work. A high unemployment rate indicates low economic growth, and a low unemployment rate indicates high economic growth of the economy.

Table 2 shows the monthly unemployment rate before and after twelve months of starting the lockdown in India due to COVID-19. It is seen from the table that COVID and the resulting prolonged lockdown have affected the unemployment rate in India very severely. The lockdown measures taken to control the corona pandemic have rendered millions of gig workers jobless, leading to a sharp rise in the unemployment rate. This lockdown not only rendered gig workers jobless but also severely affected many white-collar jobs, especially in sectors such as aviation, tourism, travel, and hospitality. As a result, India's urban unemployment rate rose to 24.95 percent and the rural unemployment rate to 22.89 percent in April 2020, while the overall rate escalated to 23.52 percent, as against 7.35 percent overall unemployment rate in the same month last year. From April 2020 to June 2020, the unemployment rate was moving between double-digit rates, and for the first time in July 2021 , the unemployment rate came down to single digits, and it was indeed a matter of relief for the Indian economy.

From June onwards, the unemployment rate started decreasing, and in July, it came down to 7.4 percent. However, the unemployment rate again rose slightly to 8.35 in August and again declined to 6.68 percent in September 2020. According to the data, unemployment again rose slightly to 7.02 percent in October and then to 6.5 percent in November 2020. After that, a wave trend of the unemployment rate was observed from December 2020 to March 2021. It is also apparent from the table that the unemployment rate of April to August 2020 and December 2020 was higher than the unemployment rate of the corresponding month of the previous year. In contrast, the unemployment rate for September to November 2020 and January 2021 to March 2021 was lower than the same months last year. The urban unemployment rate was always higher than the rural unemployment rate during every month of the FY 2020-21, except for December, in which the rural unemployment rate was higher than the urban one.

Table 2: Unemployment Rate $(\%)$ in India

\begin{tabular}{|l|c|c|c|c|c|c|}
\hline \multirow{2}{*}{ Month } & \multicolumn{3}{|c|}{ F.Y. 2019-20 } & \multicolumn{3}{c|}{ F.Y. 2020-21 } \\
\cline { 2 - 7 } & Rural & Urban & Total & Rural & Urban & Total \\
\hline April & 7.25 & 7.57 & 7.35 & 22.89 & 24.95 & 23.52 \\
\hline May & 6.3 & 8.58 & 7.03 & 21.11 & 23.14 & 21.73 \\
\hline June & 7.69 & 8.26 & 7.87 & 9.49 & 11.68 & 10.18 \\
\hline July & 6.9 & 8.3 & 7.34 & 6.51 & 9.37 & 7.4 \\
\hline August & 7.48 & 9.71 & 8.19 & 7.65 & 9.83 & 8.35 \\
\hline September & 5.99 & 9.58 & 7.14 & 5.88 & 8.45 & 6.68 \\
\hline October & 8.02 & 8.27 & 8.1 & 6.95 & 7.18 & 7.02 \\
\hline November & 6.45 & 8.88 & 7.23 & 6.24 & 7.07 & 6.5 \\
\hline December & 6.93 & 9.02 & 7.6 & 9.15 & 8.84 & 9.06 \\
\hline January & 6.06 & 9.7 & 7.22 & 5.81 & 8.09 & 6.52 \\
\hline February & 7.34 & 8.65 & 7.76 & 6.85 & 6.99 & 6.89 \\
\hline March & 8.44 & 9.41 & 8.75 & 6.15 & 7.27 & 6.5 \\
\hline
\end{tabular}

Source: Centre for Monitoring Indian Economy Pvt. Ltd.(CMIE) 
Figure 2 exhibits the monthly unemployment rate in India for FY 2019-20 and FY 2020-21.

\section{Figure 2: Unemployment Rate (\%) in India}

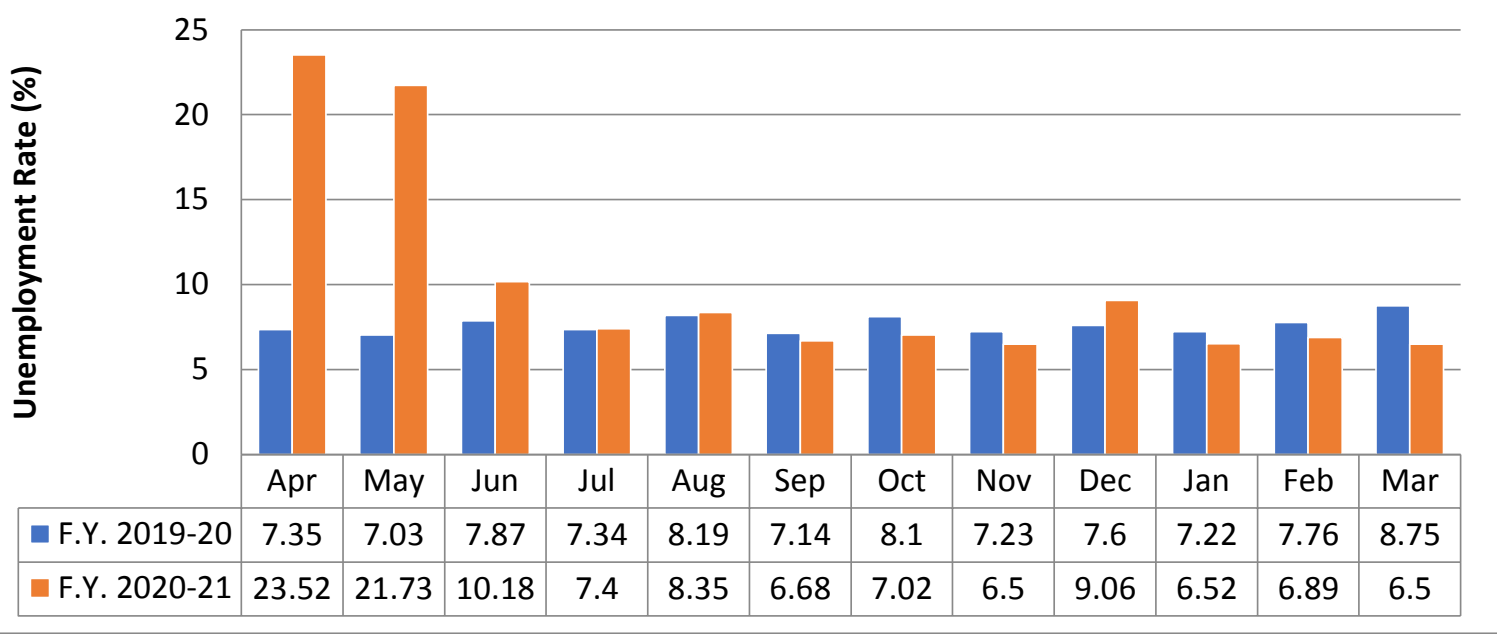

\subsection{IMPACT OF COVID ON INTERNATIONAL TRADE (NET EXPORT) IN INDIA}

International trade has two essential aspects, export, and import. Generally, exports represent favorable economic activity, better employment within the country, reasonable foreign reserves, and a good sign for the economy. However, we must also consider the components of exports. For example, the Export of finished goods can be more profitable for the economy than the Export of raw materials. Imports represent the quantity of goods and services purchased from a foreign country. Generally, higher imports represent unfavorable economic activity and an unfavorable trade balance. But we must also consider the import component. For example, the import of capital goods may be favorable for the country compared to consumer goods. Net Export represents the difference between total Export and total import during a specific period.

International trade has been harshly affected due to quiescent transport and distribution system in prolonged lockdown. A sudden drop of 39.63\% in exports and 50.94\% in imports in April 2020 compared to 2019 points to the same thing.

Table 3: India's Total Export during Financial Year 2019-20 \& 2020-21 along with percentage Growth

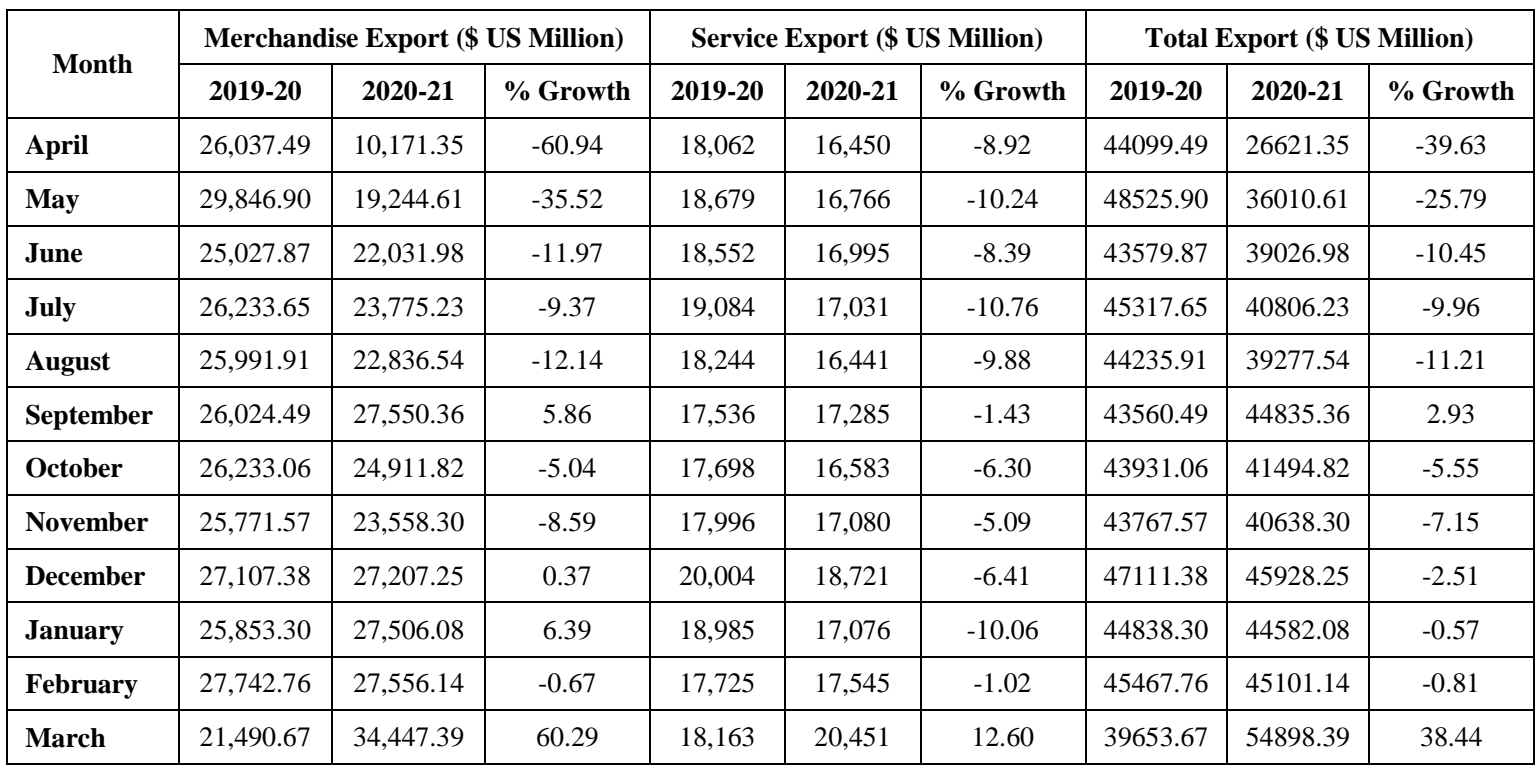

Source: Ministry of Commerce and Industry, Government of India \& Reserve Bank of India

It can be seen from Table 3 that India's total exports in April 2020 were US\$ 26,621.35 million, showing negative growth of (-) 39.63 percent over the corresponding period of the previous year. Total merchandise exports stood at US\$ 10,171.35 million in April 2020 as compared to US\$ 26,037.49 million in 
April 2019, showing negative growth of (-)60.94 percent. Similarly, the total value of the exports of services for April 2020 is US\$ 16,450 million, registering a negative growth of (-) 8.92 percent as compared to US\$ 18,062 million in April last year. The decline in exports is mainly owing to the ongoing global slowdown, exacerbated by the current COVID-19 crisis. As a result, India's total exports witnessed a positive growth of 2.93 percent (5.86 percent in the case of Merchandise Export) in September 2020 for the first time after five consecutive months of negative growth. Exports in March 2021 were the highest ever in the FY 2020-21 as the total exports in March 2021 stood at US\$ 54,898.39 million (including exports of services and goods). The total exports in March 2021 increased by $38.44 \%$ as compared to the same month last year. During the FY 2020-21, the service exports registered a positive growth of 12.60 percent in March only.

Table 4: India's Total Import during Financial Year 2019-20 \& 2020-21 along with percentage Growth

\begin{tabular}{|c|c|c|c|c|c|c|c|c|c|}
\hline \multirow{2}{*}{ Month } & \multicolumn{3}{|c|}{ Merchandise Import (\$ US Million) } & \multicolumn{3}{|c|}{ Service Import (\$ US Million) } & \multicolumn{3}{|c|}{ Total Import (\$ US Million) } \\
\hline & 2019-20 & $2020-21$ & \% Growth & 2019-20 & 2020-21 & $\%$ Growth & 2019-20 & $2020-21$ & \% Growth \\
\hline April & 42387.26 & 17086.82 & -59.69 & 11402 & 9301 & -18.43 & 53789.26 & 26387.82 & -50.94 \\
\hline May & 46683.35 & 22860.53 & -51.03 & 12492 & 9938 & -20.45 & 59175.35 & 32798.53 & -44.57 \\
\hline June & 41032.49 & 21323.55 & -48.03 & 11758 & 9960 & -15.29 & 52790.49 & 31283.55 & -40.74 \\
\hline July & 40430.65 & 29063.54 & -28.12 & 12829 & 10047 & -21.69 & 53259.65 & 39110.54 & -26.57 \\
\hline August & 39852.08 & 31032.66 & -22.13 & 12006 & 9597 & -20.06 & 51858.08 & 40629.66 & -21.65 \\
\hline September & 37694.82 & 30516.65 & -19.04 & 11096 & 10135 & -8.66 & 48790.82 & 40651.65 & -16.68 \\
\hline October & 37986.37 & 33954.00 & -10.62 & 10864 & 9525 & -12.33 & 48850.37 & 43479.00 & -11.00 \\
\hline November & 38523.25 & 33755.08 & -12.38 & 11472 & 10120 & -11.79 & 49995.25 & 43875.08 & -12.24 \\
\hline December & 39594.12 & 42877.59 & 8.29 & 12555 & 11500 & -8.40 & 52149.12 & 54377.59 & 4.27 \\
\hline January & 41149.50 & 41948.86 & 1.94 & 12001 & 10098 & -15.86 & 53150.50 & 52046.86 & -2.08 \\
\hline February & 37904.47 & 40540.42 & 6.95 & 11067 & 10613 & -4.10 & 48971.47 & 51153.42 & 4.46 \\
\hline March & 31470.92 & 48383.39 & 53.74 & 11112 & 12537 & 12.82 & 42582.92 & 60920.39 & 43.06 \\
\hline
\end{tabular}

Source: Ministry of Commerce and Industry, Government of India \& Reserve Bank of India

Table 4 shows that India's total imports in April 2020 were US\$ 26,387.82 million, showing negative growth of (-) 50.94 percent over the corresponding period of the previous year. Total merchandise import stood at US\$ 17,086.82 million in April 2020 as compared to US\$ 42,387.26 million in April 2019, exhibiting a negative growth of (-)59.69 percent. Likewise, the total value of the import of services for April 2020 is US\$ 9301 million, registering a adverse growth of (-) 18.43 percent as compared to US\$11,402 million in April last year. The drop in imports was mainly owing to the slowdown of economic activity everywhere, as the lockdown was extended due to the current COVID-19 crisis. As a result, India's total import witnessed a positive growth of 4.27 percent (8.29 percent in the case of Merchandise Import) in December 2020 for the first time after eight consecutive months of negative growth. Import in March 2021 was the highest ever in the FY 2020-21 as the total import in March 2021 stood at US\$ 60,920.39 million (including import of services and goods). The total import in March 2021 increased by $43.06 \%$ as compared to the same month last year. During the FY 2020-21, the service import registered a positive growth of 12.82 percent in March only.

Table 5 represents India's net export in the US \$ million from April 2019 to March 2021. Despite the widespread lockdown, India's trade balance remained positive from April to July. This has been made possible by a sharp drop in imports owing to the shrinkage of demand in the real economy. This was generally unexpected as there has not been a single year since 1976-77 when India did not have a considerable merchandise trade deficit. 
Table 5: India's Net Export during Financial Year 2019-20 \& 2020-21

\begin{tabular}{|l|c|c|c|c|c|c|}
\hline \multirow{2}{*}{ Month } & \multicolumn{3}{|c|}{ 2019-20 (\$ US Million) } & \multicolumn{3}{c|}{ 2020-21 (\$ US Million) } \\
\cline { 2 - 7 } & Export & Import & Net Export & Export & Import & Net Export \\
\hline April & $44,099.49$ & $53,789.26$ & $-9,689.77$ & 26,621 & 26387.82 & 233.53 \\
\hline May & $48,525.90$ & $59,175.35$ & $-10,649.45$ & 36,011 & 32798.53 & 3212.08 \\
\hline June & $43,579.87$ & $52,790.49$ & $-9,210.62$ & 39,027 & 31283.55 & 7743.43 \\
\hline July & $45,317.65$ & $53,259.65$ & $-7,942.00$ & 40,806 & 39110.54 & 1695.69 \\
\hline August & $44,235.91$ & $51,858.08$ & $-7,622.17$ & 39,278 & 40629.66 & -1352.12 \\
\hline September & $43,560.49$ & $48,790.82$ & $-5,230.33$ & 44,835 & 40651.65 & 4183.71 \\
\hline October & $43,931.06$ & $48,850.37$ & $-4,919.31$ & 41,495 & 43479.00 & -1984.18 \\
\hline November & $43,767.57$ & $49,995.25$ & $-6,227.68$ & 40,638 & 43875.08 & -3236.78 \\
\hline December & $47,111.38$ & $52,149.12$ & $-5,037.74$ & 45,928 & 54377.59 & -8449.34 \\
\hline January & $44,838.30$ & $53,150.50$ & $-8,312.20$ & 44,582 & 52046.86 & -7464.78 \\
\hline February & $45,467.76$ & $48,971.47$ & $-3,503.71$ & 45,101 & 51153.42 & -6052.28 \\
\hline March & $39,653.67$ & $42,582.92$ & $-2,929.25$ & 54,898 & 60920.39 & -6022.00 \\
\hline
\end{tabular}

Source: Ministry of Commerce and Industry, Government of India \& Reserve Bank of India

The monthly Net Export (US\$ million) of India for FY 2019-20 and FY 2020-21 has also been portrayed through chart.

\section{Figure 3: Net Export (\$ US Million) of India}

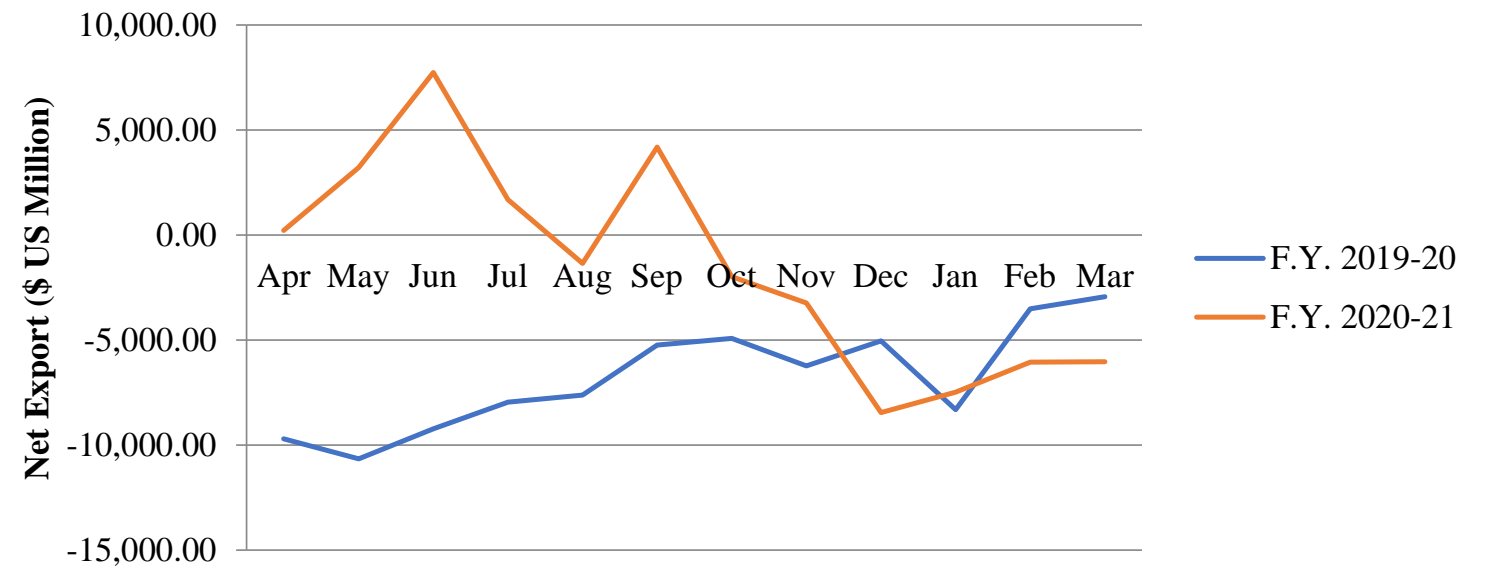

\subsection{IMPACT OF COVID ON GOODS AND SERVICE TAX COLLECTION IN INDIA}

Goods and Services Tax is a harmonized indirect tax collected at each stage of value addition of taxable supplies in India. It is a consumption-based value-added tax levied on the supply of goods and specific services. It represents the volume of economic activities such as production, distribution, consumption, trade, and commerce of India.

The nationwide lockdown of 68 days from March 25 last year had a disastrous impact on the economy and consequently impacted the GST collections in the first and second quarters of the financial year 2020-21. Table-6 indicates monthly GST collection in India from April 2019 to March 2021. The table shows that the GST collection has been amply crushed from April 2020 to August 2020. The GST collection was ₹ 1,13,865 crore in April 2019, and it was accounted for ₹ 32,294 crores in April 2020, which indicates a drop of 71.64\% in growth rate. As business activities came to a factual pause in the month of April due to the pandemic lockdown, the reduction in Goods and Services Tax collection points directly to this issue. However, the same situation of negative growth can also be seen in May 2020 and June 2020. After an unremitting negative growth from April 2020 to August 2020, the Goods and Services Tax (GST) revenue collection stood at ₹ 95,480 crores for the first 
time in September, registering a growth of 3.88 percent over the previous year's ₹ 91,917 crores in the same month.

However, after registering a negative growth of $41.03 \%$ and $7.83 \%$ in the first and second quarters, the third and fourth quarters saw favorable growth rates of $7.69 \%$ and $13.74 \%$, which was indeed a piece of relief news for the Indian economy. If the GST revenue collection for the last six months is taken into account, it can be observed that the GST revenue in these months has been more than Rs 1 lakh crore, which is a clear indicator of the rapid economic recovery in this post-pandemic period. The Goods and Services Tax (GST) revenue collected in March 2021 was the highest ever in FY 2020-21 as the Government collected ₹ 1,23,902 crore in March 2021. The GST collection for March is $26.95 \%$ higher than the corresponding month of last year.

Table 6 : Month-wise collection of GST Revenue in F.Y 2019-20 \& 2020-21

\begin{tabular}{|l|r|r|r|r|r|r|r|r|r|r|r|}
\hline \multirow{2}{*}{ Month } & \multicolumn{4}{|c|}{ F.Y. 2019-20 ( ₹ Crore) } & \multicolumn{5}{|c|}{ F.Y. 2020-21 ( ₹ Crore) } & \multirow{2}{*}{$\begin{array}{c}\text { \% } \\
\text { Growth }\end{array}$} \\
\cline { 2 - 14 } & CGST & SGST & IGST & CESS & Total & CGST & SGST & IGST & CESS & Total & NA \\
\hline April & 21163 & 28801 & 54733 & 9168 & 113865 & NA & NA & NA & NA & 32,294 & -71.64 \\
\hline May & 17811 & 24462 & 49891 & 8125 & 100289 & NA & NA & NA & NA & 62,009 & -38.17 \\
\hline June & 18366 & 25343 & 47772 & 8457 & 99938 & 18,980 & 23,970 & 40,302 & 7,665 & 90,917 & -9.03 \\
\hline July & 17912 & 25008 & 50612 & 8551 & 102083 & 16,147 & 21,418 & 42,592 & 7,265 & 87,422 & -14.36 \\
\hline August & 17733 & 24239 & 48958 & 7273 & 98203 & 15,906 & 21,064 & 42,264 & 7,215 & 86,449 & -11.97 \\
\hline September & 16630 & 22598 & 45069 & 7620 & 91917 & 17,741 & 23,131 & 47,484 & 7,124 & 95,480 & 3.88 \\
\hline October & 17582 & 23674 & 46517 & 7607 & 95380 & 19,193 & 25,411 & 52,540 & 8,011 & $1,05,155$ & 10.25 \\
\hline November & 19592 & 27144 & 49028 & 7727 & 103491 & 19,189 & 25,540 & 51,992 & 8,242 & $1,04,963$ & 1.42 \\
\hline December & 19962 & 26792 & 48099 & 8331 & 103184 & 21,365 & 27,804 & 57,426 & 8,579 & $1,15,174$ & 11.62 \\
\hline January & 20944 & 28224 & 53013 & 8637 & 110818 & 21,923 & 29,014 & 60,288 & 8,622 & $1,19,847$ & 8.15 \\
\hline February & 20569 & 27348 & 48503 & 8947 & 105366 & 21,092 & 27,273 & 55,253 & 9,525 & $1,13,143$ & 7.38 \\
\hline March & 19183 & 25601 & 44508 & 8306 & 97597 & 22,973 & 29,329 & 62,843 & 8,757 & $1,23,902$ & 26.95 \\
\hline Total & $\mathbf{2 2 7 4 4 7}$ & $\mathbf{3 0 9 2 3 4}$ & $\mathbf{5 8 6 7 0 3}$ & $\mathbf{9 8 7 4 9}$ & $\mathbf{1 2 2 2 1 3 1}$ & $\mathbf{1 , 9 4 , 5 0 9}$ & $\mathbf{2 5 3 9 5 4}$ & $\mathbf{5 , 1 2 , 9 8 4}$ & $\mathbf{8 1 0 0 5}$ & $\mathbf{1 1 , 3 6 , 7 5 5}$ & $\mathbf{- 6 . 9 9}$ \\
\hline
\end{tabular}

Source: Official website of GST Council

The monthly collection of GST (₹ in crore) in India for FY 2019-20 and FY 2020-21 has also been depicted through a chart.

\section{Figure 4: GST Collection in FY 2019-20 \& FY 2020-21}

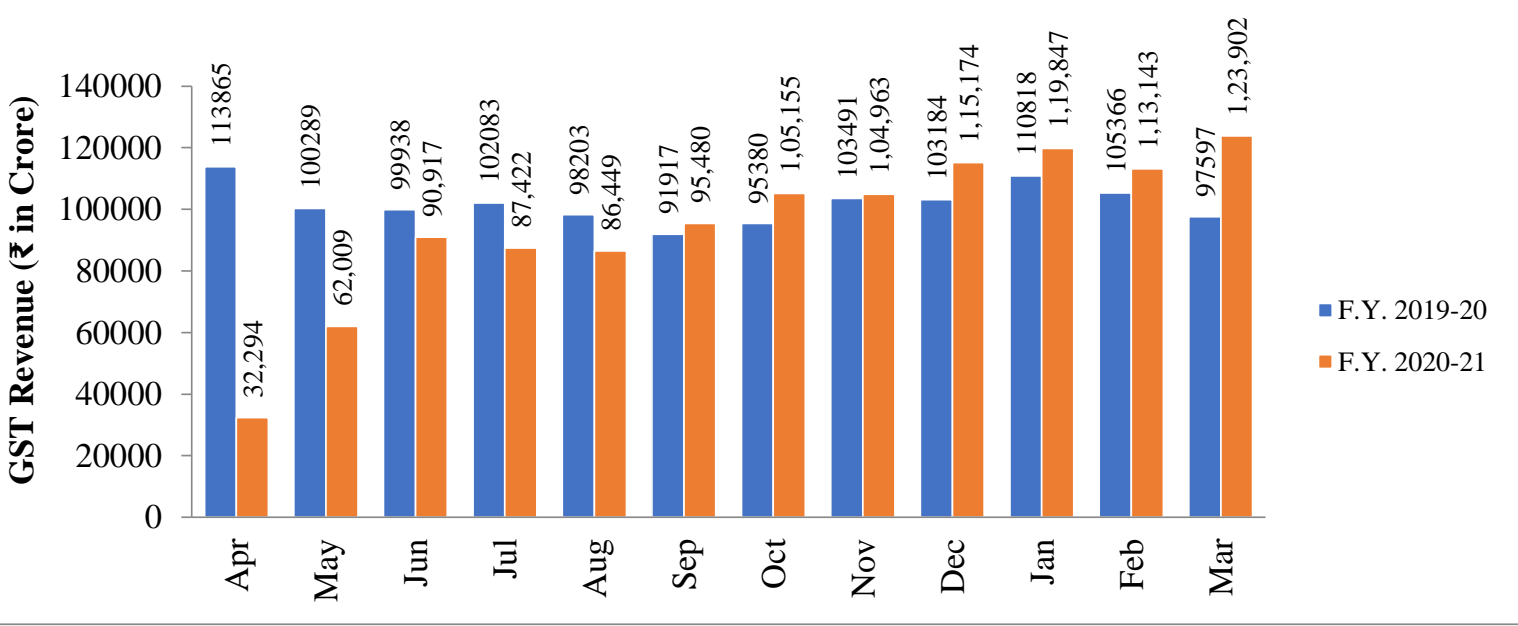

\subsection{HYPOTHESIS TESTING}

In order to achieve the precise objectives of 2019-20 is taken as the period before COVID, while the FY 2020-21 is considered as the period during COVID. the study and to test the research hypothesis, the paired t-test has been chosen here. Therefore, the FY 
Table 7: Paired Samples Test (FY 2019-20 \& FY 2020-21)

\begin{tabular}{|c|c|c|c|c|c|c|c|c|}
\hline & \multicolumn{5}{|c|}{ Paired Differences } & \multirow{3}{*}{$\mathbf{t}$} & \multirow{3}{*}{ df } & \multirow{3}{*}{$\begin{array}{l}\text { Sig. } \\
\text { (2-tailed) }\end{array}$} \\
\hline & \multirow[t]{2}{*}{ Mean } & \multirow{2}{*}{ Std. Deviation } & \multirow{2}{*}{$\begin{array}{l}\text { Std. Error } \\
\text { Mean }\end{array}$} & \multicolumn{2}{|c|}{$\begin{array}{l}\text { 95\% Confidence Interval of the } \\
\text { Difference }\end{array}$} & & & \\
\hline & & & & Lower & Upper & & & \\
\hline GDP Growth Rate & 11.5000 & 13.0747 & 6.5373 & -9.3047 & 32.3047 & 1.759 & 3 & .177 \\
\hline Unemployment Rate & -2.3975 & 6.2107 & 1.7929 & -6.3436 & 1.5486 & -1.337 & 11 & .208 \\
\hline Net Export & -5315.0992 & 6781.3315 & 1957.6018 & -9623.7516 & -1006.4467 & -2.715 & 11 & .020 \\
\hline GST Collection & 7114.6667 & 28658.4505 & 8272.9820 & -11094.0440 & 25323.3774 & .860 & 11 & .408 \\
\hline
\end{tabular}

Source: Own Computation

Table 7 exposes the paired sample test for all indicators of the economy considered under this study. While testing the paired t-test, a significance level of 0.05 is chosen, and the two-tailed test has opted in this case. The significance value, which is more than 0.05 , indicates a non-rejection of the hypothesis that states no significant difference in the indicators of the economy considered here before and during the COVID. However, the significance value for only one indicator, i.e., Net Export of India, is less than 0.05, indicating a statistically noteworthy difference in Net Export of India before and during COVID. Regarding other indicators, it is noticeable that the significance value is more than 0.05 , hence not statistically significant, indicating no substantial difference in those indicators before and during COVID.

\section{CONCLUSION}

In the present paper, an endeavour was made to conduct an in-depth and detailed study to assess the immediate impact of COVID-19 on the Indian economy's various indicators such as GDP, unemployment rate, net exports, and GST collections to assess the immediate impact of COVID-19. Certainly, COVID-19 has gravely affected all the indicators of the Indian economy under consideration in the first quarter and second quarter of the financial year 2020-21, but the third and fourth quarters did not show any such peak impact of the pandemic. Instead, it appears that the Indian economy was coming out of the pandemic-induced degrowth during this period. After deteriorating in the first and second quarters of the financial year 2020-21, the GDP growth rate registered an upward trend in the third and fourth quarters. The unemployment rate also declined to a single digit from the second quarter of the financial year 2020-21, growing in double digits in the first quarter. India's total exports also registered positive growth in the third and fourth quarters of FY 2020-21 after two consecutive quarters of negative growth. If the GST revenue collection of the last two quarters is taken into account, it can be seen that the GST revenue in these months was over ₹ 1 lakh crore. The main reason for this rapid recovery from the effects of the pandemic was the further relaxation of the lockdown and the various steps taken by the Government to get rid of the devastating effects of the pandemic.

\section{REFERENCES}

1. B. Kapasi, and M.K. Kurmi (2021), "A Knock around the Economic Impact of COVID-19 with reference to the quantum of Goods and Services Tax Collection in India", EPRA International Journal of Multidisciplinary Research (IJMR), Vol. 7, No. 5, pp. 121-126

2. HaiYue Liu, Aqsa Manzoor, CangYu Wang, Lei Zhang and Zaira Manzoor (2020), "The COVID-19 Outbreak and Affected Countries Stock Markets Response", International Journal of Environmental Research and Public Health, Vol 17, No. 8, pp. 1-19

3. J.D. Sonkhaskar (2020), "A Study on Impact of Covid-19 on Indian Economy", International Journal of Advanced Science and Technology, Vol.29, No. 12, pp. 432-439

4. K. D. Garg, M. Gupta, and M. Kumar (2020), "The Impact of COVID-19 Epidemic on Indian Economy Unleashed By Machine Learning", IOP Conf. Series: Materials Science and Engineering, ICCRDA 2020, IOP Publishing, pp.1-12

5. M. Chaudhary, P. R. Sodani, and S. Das (2020), "Effect of COVID-19 on Economy in India: Some Reflections for Policy and Programme", Journal of Health Management, Vol. 22, No. 2, pp. 169-180

6. N. Arora and V. Gupta(2020), "A Study on Impact of COVID-19 on Indian Economy", International Journal of Social Science and Research, July 2020, Volume 9 Issue 7, pp. 1516 - 1519

7. S. Agarwal and A. Singh (2020), "Covid-19 and Its Impact on Indian Economy", International Journal of Trade and Commerce-IIARTC, Vol. 9, No. 1, pp. 72-79 